\title{
Hubungan Antara Lama Sakit dengan Kualitas Hidup Anak Penderita DMT1 Saat Pandemi Covid-19 di RSUD Soetomo Surabaya
}

\author{
Kevin Almas Maromi*, Nur Rochmah, Bambang Hermanto \\ Program Studi Kedokteran, Fakultas Kedokteran, Universitas Airlangga Surabaya \\ *Correspondence email: kevin.almas.maromi-2018@ @ fk.unair.ac.id
}

\begin{abstract}
Abstrak. Penelitian ini bertujuan untuk mengetahui hubungan lama sakit dengan kualitas hidup dari penderita Diabetes Melitus tipe 1 saat pandemi COVID-19 perlu untuk diteliti lebih lanjut. Penelitian ini merupakan penelitian deskripsi analitik dengan pendekatan penelitian cross-sectional menggunakan kuesioner dengan teknik wawancara per telepon. Kuesioner dalam penelitian ini didasari oleh beberapa guideline dan penelitian sebelumnya. Pengukuran menggunakan PedsQ1 3.2 Diabetes Module. Data dikumpulkan dengan menggunakan kuesioner tervalidasi yang terdiri dari 33 item pertanyaan. Data diambil selama Oktober 2020. Sebanyak 33 kuesioner berhasil disebarkan pada pasien di Poli Anak RSUD Dr. Soetomo Surabaya yang berpartisipasi dalam penelitian ini. Data kemudian dianalisis dengan uji non-parametrik dengan metode Spearman correlation test menggunakan IBM SPSS Statistics 25. Berdasarkan penilaian kualitas hidup dengan kuesioner PedsQL, sebanyak 17 responden (51,6\%) memiliki kualitas hidup mendekati buruk, dan 16 responden kualitas hidupnya mendekati baik. Domain yang paling terganggu adalah yang berkaitan dengan kekhawatiran, yaitu sebanyak 20 responden (60,7\%). Sementara itu, proporsi responden dengan kualitas yang mendekati baik paling besar terdapat pada pengobatan I sebanyak 19 responden $(57,6 \%)$. Didapatkan pula adanya korelasi yang positif dan signifikan antara berkaitan dengan penyakitnya, $P$ Value $0.007<0.05$, berkaitan dengan pengobatan $\mathrm{I}, P$ Value $0.011<0.05$, berkaitan dengan kekhawatiran, $P$ value $0.009<0.05$, dan berkaitan dengan komunikasi, $P$ Value sebesar $0,016<$ 0,05 . Selain itu juga didapatkan adanya hubungan negatif yang signifikan terhadap berkaitan dengan pengobatan II, $P$ Value 0.000 $<0.05$.
\end{abstract}

Kata kunci: Kualitas Hidup; Lama Sakit; Penderita DMT1

Abstract. This study aims to determine the relationship between length of illness and quality of life of people with Type 1 Diabetes Mellitus during the COVID-19 pandemic. This research is an analytical description study with a cross-sectional research approach using a questionnaire with telephone interview techniques. The questionnaire in this study was based on several guidelines and previous research. Measurements using PedsQl 3.2 Diabetes Module. Data were collected using a validated questionnaire consisting of 33 question items. The data was collected during October 2020. A total of 33 questionnaires were successfully distributed to patients at the Children's Clinic of Dr. RSUD Dr. Soetomo Surabaya who participated in this research. The data were then analyzed by non-parametric test using the Spearman correlation test method using IBM SPSS Statistics 25. Based on the quality of life assessment using the PedsQL questionnaire, 17 respondents (51.6\%) had a near-poor quality of life, and 16 respondents had a near-good quality of life. The most disturbed domain is related to worry, which is as many as 20 respondents (60.7\%). Meanwhile, the proportion of respondents with the highest quality approaching good was found in treatment I as many as 19 respondents (57.6\%). There was also a positive and significant correlation between related to the disease, $P$ Value $0.007<0.05$, related to treatment $I, P$ Value $0.011<0.05$, related to anxiety, $P$ value $0.009<0.05$, and related to communication, $P$ Value of $0.016<0.05$. In addition, there was also a significant negative relationship with regard to treatment II, $P$ Value $0.000<0.05$.

Keywords: Quality of Life; Sick duration; Patients with DMT1

\section{PENDAHULUAN}

Diabetes Melitus tipe 1 merupakan keadaan hiperglikemia kronik di darah yang disebabkan ketika tubuh kurang atau sama sekali tidak memproduksi insulin. Manajemen DMT1 yang tidak optimal dapat memicu timbulnya komplikasi makro dan mikrovaskuler. Hal ini dapat mempengaruhi kualitas hidup pasien. Penyakit ini juga bisa menyebabkan masalah psikososial utama bagi penderita dan keluarganya. Perkembangan penyakit selama waktu yang dihabiskan perkembangan fisik dan psikososial dapat mengganggu kepuasan pribadi individu dalam individu tersebut, gejala sisa fisik, mental dan sosial dapat dilihat (Loonen et al., 2001). Masalah perkembangan dan perbaikan anak-anak dengan penyakit yang terus-menerus dan tentang cara anak itu mendapatkan dirinya sendiri, penyakitnya, terapi yang dia dapatkan dan lewati (Soetjiningsih, 2003). Berlarutlarut dan rawat inap yang tak henti-hentinya, tindakan pengobatan yang menyakitkan dan renungan tentang apa yang akan datang meragukan, kondisi ini memiliki konsekuensi nyata bagi kesejahteraan mereka sejauh kepuasan pribadi mereka (Eiser, 1997).

Dewasa ini pandemi COVID-19 masih berlangsung. Diabetes melitus adalah sebagian komorbid yang sering ditemukan pada pasien COVID-19. Data menunjukkan peningkatan risiko komplikasi DMT1 baik oleh karena proses akut maupun kronis pada pandemi COVID-19 membuat virus semakin merajalela merusak organ. Pada kasus yang fatal, maka bisa menyebabkan 
kerusakan organ yang berujung kematian. Data RSUD Dr. Soetomo menunjukkan peningkatan $\mathrm{HbA1c}$ selama pandemi ini (data poli endokrin anak, 2020). Hubungan antara lama sakit dan kualitas hidup pada pasien DMT1 saat pandemi COVID-19 masih kontroversi.

Diabetes Melitus tipe 1 (DMT1) juga pada dasarnya salah satu penyakit kronis yang sangat umum, mempengaruhi 1 dari setiap 400-600 anak dan remaja (Ali et al., 2017). Kejadian Diabetes Melitus tipe 1 pada anak di dunia maupun Indonesia terus meningkat. Pada sebelum pandemi COVID-19, tahun 2018, berdasarkan data Ikatan Dokter Anak Indonesia (IDAI) terhitung ada 1220 penderita dan pada usia 0-18 tahun meningkat $700 \%$ selama kurun waktu 10 tahun terakhir. Provinsi DKI Jakarta, Jawa Barat, Jawa Timur dan Sumatera Selatan menjadi provinsi penyumbang kasus terbanyak anak dan remaja penderita Diabetes Melitus tipe 1 (IDAI, 2018). Data dari International Diabetes Federation (IDF) mencatat bahwa dari 220 negara di dunia, Indonesia menduduki peringkat ke-7 dalam jumlah penderita diabetes.

Data sebelum pandemi COVID-19, tahun 2013, didapatkan mengenai kualitas hidup pada pasien anak penderita DMT1 dan orang tua mereka secara konsisten melaporkan skor Health-Related Quality of Life (HRQoL) yang lebih rendah dengan rentang waktu sakit yang lama dibandingkan dengan kontrol yang sehat. Kontrol metabolik, diukur dengan HbA1c nilai, secara signifikan terkait dengan kualitas hidup pada pasien melalui diabetes. (Rasoul et al., 2013)

Sedangkan, pada pandemi COVID-19 penderita Diabetes Melitus sangat rentan terhadap virus SARSCoV-2 karena kadar glukosa yang tinggi. Di Negara Cina, tingkat kematian diabetes yang terdiagnosis COVID-19 yaitu 7,3\% dan Negara Italia kematian pada pasien COVID-19 terdapat $36 \%$ kematian pasien COVID-19 diidentikkan dengan diabetes. Sebuah laporan dari Filipina - Departemen Kesehatan menggambarkan mengenai diabetes maupun hipertensi adalah penyakit penyerta yang paling banyak diketahui dalam kematian pasien COVID-19 di Filipina. Setiap penderita diabetes membawa tidak kurang dari empat protes yang diidentikkan dengan diabetes. Keluhan yang berhubungan dengan diabetes secara langsung dapat mencakup berat badan, hipertensi, neuropati, nefropati, penyakit jantung coroner (PJK), maupun stroke. Sehingga sangat memungkingkan sekali dapat mempengaruhi kualitas hidup nya dari segi jasmani dan rohani. Pandemi COVID-19 saat ini telah memaksa tenaga medis untuk mencari pendekatan alternatif untuk menangani penderita diabetes dengan urgensi dan efisiensi yang lebih tinggi dari sebelumnya. Dikarenakan belum adanya penelitian terbaru mengenai Diabetes Melitus saat pandemi COVID-19 mengenai kualitas hidup, maka contoh kasus yang serupa dengan pandemi COVID-19 ini adalah bencana gunung berapi meletus. Hasil penelitian menunjukkan melalui sesudah bencana gunung meletus terjadi komplikasi yang serius dan penurunan kualitas hidup penderita Diabetes Melitus (Nugroho Susanto, 2010).

Kualitas hidup pada penderita Diabetes Melitus dapat juga dipengaruhi oleh faktor internal, seperti tingkat pendidikan, sosio-ekonomi dan pola hidup orang tua dan bahkan penderita memerlukan rawat inap yang cukup lama di rumah sakit sehingga mereka merasa seakan-akan berbeda dari anak dan remaja normal seusia nya. Sudut pandang lain yang mempengaruhi kepuasan pribadi pasien Diabetes Mellitus adalah lamanya penderitaan (Luckman dan Sorensen's, 2000). Jadi istilah diabetes mellitus terkait dengan bahaya beberapa selukbeluk yang muncul beberapa waktu kemudian. Faktor utama yang memicu kompleksitas yang terpisah dari toleransi adalah keseriusan diabetes. Bagaimanapun, rentang panjang diabetes mellitus diimbangi dengan gaya hidup yang sehat yang akan menghasilkan kepuasan pribadi yang layak, sehingga dapat mencegah atau menunda kebingungan jangka panjang (Zimmet, 2009).

Yusra (2011), berpendapat bahwa lama menderita juga pasti mempengaruhi kualitas hidupnya. Pasien yang pernah mengalami infeksi $>5$ tahun atau dikatakan mengalami akibat buruk dari penyakit yang sedang berlangsung mempunyai kemampuan hidup yang lebih baik daripada pasien yang mengalami akibat buruk dari infeksi $<5$ tahun atau mengalami akibat sakit dari penyakit yang berat, hal tersebut pada alasan bahwa pasien memiliki wawasan dalam menghadapi penyakitnya dan memiliki adaptasi yang baik.

Penilaian kualitas hidup juga dapat digunakan sebagai alasan untuk mengatur program administrasi, memeriksa kemajuan klinis maupun hasil pengobatan agar selanjutnya diharapkan bisa mengurangi tingkat ketergantungan maupun beban pada pasien, keluarga, dan iklim umum.

Oleh karena itu, melihat angka kejadian penyakit Diabetes Melitus tipe 1 yang cukup tinggi di Indonesia, dan lama sakit mempengaruhi komplikasi sehingga dapat menurunkan kualitas hidup, serta Diabetes Melitus menjadi penyakit penyerta yang berisiko tinggi untuk fatal jika terinfeksi virus COVID-19. Selain itu dikarenakan masih sedikitnya penelitian tentang kualitas hidup penderita Diabetes Melitus saat pandemi COVID19. Maka dari itu, penelitian mengenai hubungan lama sakit dengan kualitas hidup dari penderita Diabetes Melitus tipe 1 saat pandemi COVID-19 perlu untuk diteliti lebih lanjut.

\section{METODE}

Penelitian ini yaitu penelitian deskripsi analitik melalui pendekatan penelitian cross-sectional menggunakan kuesioner dengan teknik wawancara per telepon. Kuesioner pada penelitian mendasari oleh sebagian guideline dan penelitian sebelumnya. Pengukuran menggunakan PedsQ1 3.2 Diabetes Module. 
Kevin Almas Maromi, Nur Rochmah dan Bambang Hermanto, Hubungan Antara Lama Sakit dengan Kualitas Hidup Anak Penderita DMT1 Saat Pandemi Covid-19 di RSUD Soetomo Surabaya

Data dikumpulkan melalui penggunaan kuesioner tervalidasi yang terdiri dari 33 item pertanyaan. Data diambil selama Oktober 2020. Sebanyak 33 kuesioner berhasil disebarkan pada pasien di Poli Anak RSUD Dr. Soetomo Surabaya yang berpartisipasi pada penelitian ini. Setelah itu data dianalisis memakai uji nonparametrik melalui metode Spearman correlation test menggunakan IBM SPSS Statistics 25.

\section{HASIL DAN PEMBAHASAN}

Penelitian ini melibatkan 33 anak penderita DMT1 saat Pandemi COVID-19 di RSUD Dr. Soetomo Surabaya. semua responden yang memenuhi kriteria inklusi berusia 5 sampai 18 tahun oleh wali anak yang bersedia dilibatkan pada penelitian.

Tabel 1. Distribusi responden

\begin{tabular}{lll}
\hline \multicolumn{1}{c}{ Karakteristik } & \multicolumn{1}{c}{ Rerata } & \multicolumn{1}{c}{ n $\%)$} \\
\hline Jenis Kelamin & & $\mathbf{1 8}(\mathbf{5 4 , 5 \% )}$ \\
Laki-Laki & & $\mathbf{1 5}(\mathbf{4 5 , 5 \% )}$ \\
Perempuan & $\mathbf{1 0 , 6}$ & \\
Usia & & $\mathbf{3}(\mathbf{9 , 1 \%})$ \\
5-7 tahun & $\mathbf{1 2}(\mathbf{3 6 , 4 \%})$ \\
8-12 tahun & $\mathbf{3 ( 9 , 1 \% )}$ \\
13-18 tahun & \\
Tingkat Pendidikan & & $\mathbf{1 8}(\mathbf{5 4 , 5 \% )}$ \\
SD & $\mathbf{1 2}(\mathbf{3 6 , 4 \%})$ \\
SMP & $\mathbf{3 ( 9 , 1 \% )}$ \\
SMA & &
\end{tabular}

Sumber : data diolah peneliti

Data pada tabel 1 menginformasikan sebagian besar responden berjenis kelamin laki-laki sebanyak 18 responden $(54,5 \%)$. Berdasarkan umur, menunjukkan bahwa sebagian besar responden berusia antara 8-12 tahun sebanyak 17 responden $(51,6 \%)$. Sedangkan, data tingkat pendidikan menggambarkan mengenai sebagian besar responden berlatar pendidikan Sekolah Dasar sebanyak 18 responden $(54,5 \%)$.

Tabel 2. Nilai Kualitas hidup responden. $(\mathrm{n}=33)$

\begin{tabular}{llll}
\hline Domain Kualitas Hidup & Rerata & Terendah & Tertinggi \\
\hline Berkaitan dengan penyakitnya & 74,3 & 56,8 & 84,8 \\
Berkaitan dengan pengobatan I & 76,9 & 63,6 & 87,8 \\
Berkaitan dengan pengobatan II & 84,2 & 73,4 & 93,9 \\
Berkaitan dengan kekhawatiran & 68,1 & 62,1 & 78,7 \\
Berkaitan dengan komunikasi & 68,1 & 68,9 & 77,2 \\
Rerata skor kualitas hidup & 74,32 & 64,96 & 84,48 \\
\hline
\end{tabular}

Sumber: data diolah peneliti

Berdasarkan tabel 5.2. rata-rata kualitas hidup responden yaitu 74,32 jumlah nilai terendahnya adalah 64,96 dan nilai tertingginya adalah 84,48 . Dari masingmasing domain, didapatkan rerata pernyataan yang berkaitan dengan penyakitnya adalah 74,3 . Rerata pernyataan yang berkaitan dengan pengobatan I dan II adalah 76,9 dan 84,2 . Serta, rerata pernyataan yang berkaitan dengan kekhawatiran dan komunikasi adalah 68,1 .
Tabel 3. Distribusi responden berdasarkan lama sakit dan skor kualitas hidup

\begin{tabular}{|c|c|c|}
\hline Lama Sakit & $\mathrm{n}(\%)$ & Mean QL \\
\hline $1-3$ tahun & $17(51,6 \%)$ & 72,9 \\
\hline $4-6$ tahun & $10(30,3 \%)$ & 74,8 \\
\hline $7-9$ tahun & $6(18,1 \%)$ & 84,3 \\
\hline
\end{tabular}

Sumber : data diolah peneliti

Berdasarkan penelitian yang sudah dilakukan, diperoleh hasil hubungan antara lama sakit dengan kualitas hidup anak penderita DMT1 saat pandemi COVID-19 di RSUD Dr. Soetomo Surabaya yaitu lama sakit rentang $1-3$ tahun sebanyak 17 responden $(51 \%, 6)$, memiliki rata-rata poin kualitas hidup sebesar 72,9 ; responden dengan lama sakit rentang 4-6 tahun sebanyak 10 responden $(30,3 \%)$, mempunyai rerata skor kualitas hidup sebesar 74,8 ; dan responden dengan lama sakit rentang $7-9$ tahun sebanyak 6 responden $(18,1 \%)$ memiliki rata-rata poin kualitas hidup senilai 84,3.

Data penelitian yang sudah didapatkan, setelah itu diolah dengan SPSS agar diketahui ada atau belum ada hubungan antara lama sakit pada kualitas hidup anak penderita DMT1 saat pandemi COVID-19 di RSUD Dr. Soetomo Surabaya.

Tabel 4. Hubungan lama sakit dengan kualitas hidup domain anak DMT1

\begin{tabular}{lcc}
\hline Domain Kualitas Hidup & $\begin{array}{c}\mathbf{R} \\
\text { (Correlation } \\
\text { Coefficient) }\end{array}$ & P Value \\
\hline Berkaitan dengan penyakitnya & 0,480 & 0,005 \\
Berkaitan dengan pengobatan I & 0,436 & 0,011 \\
Berkaitan dengan pengobatan II & $-0,578$ & 0,000 \\
Berkaitan dengan kekhawatiran & 0,445 & 0,009 \\
Berkaitan dengan komunikasi & 0,417 & 0,016 \\
Kualitas Hidup Total & 0,371 & 0,034 \\
\hline
\end{tabular}

Sumber : data diolah peneliti

Domain yang berkaitan dengan penyakitnya memiliki Nilai Correlation Coefficient bernilai positif sebesar 0,459 (Korelasi Cukup) maupun $P$ Value sebesar $0,007<0,05$ sehingga bisa dibuat kesimpulan mengenai lama sakit memiliki hubungan (positif) secara signifikan dengan kualitas hidup yang berkaitan dengan penyakitnya. Domain yang berkaitan dengan pengobatan I memiliki Nilai Correlation Coefficient bernilai positif sebesar 0,436 (Korelasi Cukup) dan $P$ Value sebesar $0,011<0,05$ sehingga bisa dibuat kesimpulan mengenai lama sakit memiliki hubungan (positif) secara signifikan dengan kualitas hidup yang berkaitan dengan pengobatan I. Domain yang berkaitan dengan pengobatan II memiliki Nilai Correlation Coefficient bernilai negatif sebesar $-0,578$ (Korelasi Kuat) dan $P$ Value sebesar $0,000<0,05$ maka bisa disimpulkan bahwa lama sakit memiliki hubungan (negatif) secara signifikan dengan kualitas hidup yang berkaitan dengan 
pengobatan II. Domain yang berkaitan dengan kekhawatiran memiliki Nilai Correlation Coefficient bernilai positif sebesar 0,445 (Korelasi Cukup) dan $P$ Value sebesar $0,009<0,05$ maka bisa disimpulkan bahwa lama sakit memiliki hubungan (positif) secara signifikan dengan kualitas hidup yang berkaitan dengan kekhawatiran. Domain yang berkaitan dengan komunikasi memiliki Nilai Correlation Coefficient bernilai positif sebesar 0,417 (Korelasi Cukup) dan $P$ Value sebesar 0,016 < 0,05 maka bisa disimpulkan bahwa lama sakit memiliki hubungan (positif) secara signifikan dengan kualitas hidup yang berkaitan dengan komunikasi.

Kualitas Hidup Total memiliki Nilai Correlation Coefficient bernilai positif sebesar 0,371 (Korelasi Cukup) dan $P$ Value sebesar 0,034 $<0,05$ maka bisa disimpulkan bahwa kualitas hidup memiliki hubungan (positif) secara signifikan dengan lama sakit.

Penilaian kualitas hidup merupakan satu dari banyak hal yang sangat penting untuk diperhatikan pada anak penderita DMT1. Penilaian ini mempunyai tujuan supaya bias melakukan pengelolaan yang lebih maksimal pada anak-anak penderita DMT1. Seperti yang ditunjukkan oleh Varni (1999), penilaian kualitas hidup bersifat emosional. Bagi orang dewasa, evaluasi diri (self report) adalah kunci yang dapat menentukan kualitas hidup mereka. Bagaimanapun, pada anak-anak, kemajuan intelektual adalah pemikiran untuk diperlakukan sebagai responden untuk penilaian kepuasan pribadi pada dirinya. Akibatnya, selama penilaian kepuasan pribadi untuk anak-anak, mereka diizinkan untuk bergabung dengan orang tua mereka (laporan perantara orang tua). PedsQL merupakan salah satu instrumen penilaian kepuasan pribadi yang dapat dimanfaatkan, baik dengan mengisi diri sendiri maupun disapa oleh wali. Sampel yang dipakai dalam penelitian ini dengan total 33 responden penderita DMT1 yang tercatat sebagai pasien di RSUD Dr. Soetomo Surabaya, dengan komposisi 17 responden dengan lama sakit ama sakit rentang $1-3$ tahun, 10 responden dengan rentang sakit selama 4 - 6 tahun, dan 6 responden dengan rentang sakit selama 7-9 tahun. Sampel diambil dari RSUD Dr. Soetomo Surabaya sejak bulan Agustus 2020.

Data sampel diperoleh dengan adanya pertanyaanpertanyaan yang diberikan untuk orang tua maupun wali pasien, maupun kepada responden secara langsung ataupun mengacu pada isi diperoleh kuesioner kualitas hidup PedsQL melalui rentang usia responden 5- 18 tahun. Pertanyaan pada kuesioner tersebut berkaitan dengan penyakitnya, pengobatan I, pengobatan II, kekhawatiran, dan komunikasi dari responden yang sifatnya umum serta mampu memahami, baik untuk peneliti ataupun dari sampel penelitian. Orang tua sampel atau responden sendiri bias diberikannya jawaban lebih kuat maupun bisa dipercaya, sesuai adanya keadaan responden di lingkungannya sekitarnya.
Berdasarkan hasil analisisnya statistik pada penelitian yang sudah dilaksanakannya, sehingga hipotesis dari penelitian hubungan lama sakit dengan kualitas hidup anak penderita DMT1 saat pandemi COVID-19 di RSUD Dr. Soetomo Surabaya bias diterimanya. Pada penelitian tersebut, dilakukan pengelompokkan lama sakit menjadi 3 kelompok, yaitu rentang sakit selama 1-3 tahun, 4-6 tahun, dan 7-9 tahun. dari kelompok responden dengan lama sakit rentang 1-3 tahun, diperolehnya rata-rata skor kualitas hidupnya sebesar 72,9; responden dengan lama sakit 4-6 tahun didapatkan skor rerata kualitas hidupnya sebesar 74,8 ; dan pada responden dengan rentang sakit selama 7-9 tahun didapatkan rerata skor kualitas hidupnya sebesar 84,3. Dari gambaran umum yang didapatkan di atas, sangat terlihat jelas mengenai adanya hubungan antara lama sakit dengan kualitas hidup anak penderita DMT1 saat pandemi COVID-19 di RSUD Dr. Soetomo Surabaya

Saputro (2008), bahwa lama sakit secara keseluruhan berhubungan dengan kualitas hidup pasien yang sebagian besar lebih rendah dalam jangka panjang diabetes. Juga, tingkat ketegangan dalam jangka panjang penyakit dapat menyebabkan penurunan kualitas hidup pasien.

Yusra (2011), berpendapat mengenai lama bertahan juga tidak diragukan lagi mempengaruhi kualitas hidup. Pasien yang pernah mengalami infeksi $>5$ tahun atau dikatakan mengalami akibat buruk penyakit terus-menerus mempunyai kemampuan hidup yang lebih baik daripada pasien yang mengalami akibat buruk akibat infeksi $<5$ tahun atau mengalami akibat sakit dari penyakit yang berat, hal ini pada alasan bahwa pasien memiliki wawasan dalam menangani penyakit mereka dan memiliki kemampuan beradaptasi yang besar..

Menurut Mandagi (2010), hal yang penting mengenai kebutuhan untuk memperkirakan kualitas hidup, khususnya pada individu dengan diabetes mellitus yaitu dengan alasan bahwa kualitas hidup adalah sebagian tujuan utamanya terapi, dikarenakan diabetes mellitus adalah infeksi konstan yang tidak dapat dihilangkan, namun dengan asumsi kadar glukosa dapat dikendalikan dengan tepat, protes yang sebenarnya, karena kesulitan atau ketidaknyamanan yang intens. infeksi yang sedang berlangsung dapat dibatasi atau dicegah. Selain itu, kualitas hidup dan masalah mental yang buruk dapat memperparah masalah metabolisme, baik secara langsung melalui tekanan hormonal, atau dengan implikasi melalui kesulitan.

Ada variabel berbeda yang belum dipertimbangkan dan dapat mempengaruhi kualitas hidup anak-anak dengan DMT1 selama pandemi COVID-19. Juga, efek samping dari ulasan ini menggambarkan kepuasan pribadi anak-anak dengan DMT1 sedikit. Untuk populasi yang lebih luas maupun kualitas yang beragam, diperlukan eksplorasi lebih lanjut. 
Kevin Almas Maromi, Nur Rochmah dan Bambang Hermanto, Hubungan Antara Lama Sakit dengan Kualitas Hidup Anak Penderita DMT1 Saat Pandemi Covid-19 di RSUD Soetomo Surabaya

\section{Perbandingan dengan Penyakit lainnya}

Penelitian ini dapat kita bandingkan dengan penelitian lainnya yang serupa. Perbedaan kualitas hidup pada anak penderita autoimun saat sebelum adanya pandemi dan saat adanya pandemi COVID-19 pun juga dapat kita bandingkan dengan beberapa penelitian terdahulu. Pada penelitian yang dilakukan oleh Joice M. Lawoh dan Debora Tampongangoy di Manado pada anak penderita autoimun sebelum pandemi, didapatkan 70 sebesar 19 responden dengan persentase 63,3\% memiliki kualitas hidup yang baik, sedangkan 11 responden dengan persentase $36,7 \%$ memiliki kualitas hidup yang buruk.

Penelitian ini juga dapat dibandingkan dengan penelitian kualitas hidup anak pada penderita penyakit genetik, seperti Thalassemia yang dilakukan oleh Locoporta Agung di Solo. Hasil pada penelitian tersebut menunjukkan bahwa sebanyak 15 dari 31 responden dengan persentase 48,39\% memiliki kualitas hidup yang buruk saat mengidap penyakit tersebut sebelum adanya pandemi. Penelitian ini pun mempunyai hasil yang hampir sama dengan penelitian yang kami lakukan saat pandemi COVID-19.

Namun, pada penelitian kami terhadap anak penderita DMT1 ini, didapatkan bahwa sebanyak 17 responden dengan persentase 51,6\% mempunyai kualitas hidup mendekati buruk dan sebanyak 16 responden dengan persentase 48,4\% mempunyai kualitas hidup mendekati baik selama adanya pandemi COVID-19.

Terdapat beberapa perbedaan dari hasil penelitian yang kami lakukan dengan penelitian serupa yang terlebih dahulu dilakukan. Hal ini disebabkan karena adanya perbedaan kondisi dan situasi, yaitu sebelum dan sesaat adanya pandemi COVID-19 yang dapat menjadi indikator kuat penentu baik atau buruknya kualitas hidup anak penderita autoimun di daerah setempat. Sedangkan faktor lainnya yang membuat adanya sedikit perbedaan pada penelitian ini adalah demografi wilayah, serta sampel yang diambil pada wilayah yang berbeda.

Anak dengan rentang sakit yang lebih lama dapat berakibat perubahan fisik pada dirinya. Perubahan fisik berakibat keterbatasan pada beraktivitas baik kualitas ataupun kuantitasnya (Locoporta, 2012)

\section{SIMPULAN}

Berdasarkan penelitian yang dilakukanya di RSUD Dr. Soetomo dapat disimpulkan bahwa terdapat hubungan (positif) signifikan dengan $P$ Value sebesar $0.034<0.05$ antara lama sakit dengan kualitas hidup anak penderita DMT1 saat Pandemi COVID-19 dala usia 5 sampai 18 tahun. Tingkat kekuatan hubungan antara kedua variabelnya memiliki Nilai Correlation Coefficient bernilai positif sebesar 0,371 termasuk dalam kategori korelasi Cukup.

\section{DAFTAR PUSTAKA}

Agung, Locoparta. (2012). Hubungan Lama Sakit Terhadap Kualitas Hidup Anak Penderita Thalassemia Di Rsud Dr. Moewardi.

Eiser, C. (1997). A review of measures of quality of life for children with chronic illness. Arch Dis Child.

Ikatan Dokter Anak Indonesia. (2018). Registri DM tipe1 pada anak. Jakarta. IDAI.

Loonen, H., Derkx, B., \& Otley, A. (2001). Measuring Health-Related Quality of Life of Pediatric Patiens. J Pediart Gastroenterol Nutr.

Luckman, \& Sorensen, S. (2000). Medikal Surgical Nersing: A Psychophysiologic Approch 4th $E d$. W.B Sauders Company.

Mandagi, A. . (2010). Faktor yang Berhubungan Dengan Status Kualitas Hidup Penderita Diabetes Mellitus. In Jurnal Penelitian Kesehatan. Universitas Airlangga Surabaya.

Nugroho, S. . (2010). Hubungan antara Tingkat Stres dengan Kadar Gula darah Pada Pasien Diabetes Melitus Di Wilayah Kerja Puskesman Sukoharjo 1 Kabupaten SukoharjoNo Title. Universitas Muhammadiyah Surakarta.

Rasoul, A. M., F, A., Z, R., \& AlShawaf. (2013). Quality of Life of Children and Adolescents with Type 1 Diabetes in Kuwait. Medical Principles and Practice, $\quad 22(4)$. https://doi.org/https://doi.org/10.1159/000347052

Saputro. (2008). Evaluasi Kualitas Hidup Pasien Diabetes Melitus Tipe 2 Rawat Jalan di RSUD Wirosaban Yogyakarta. Universitas Islam Indonesia.

Soetjiningsih. (2003). Tumbuh Kembang Anak. EGC.

Varni JW, Seid M, Kurtin PS. (1999) Pediatric healthrelated quality of life measurement technology: A Guide for Health Care Decision Makers. JCOM. $33--40$

Yusra, A. (2011). Hubungan Antara Dukungan Keluarga Dengan Kualitas Hidup Pasien Diabetes Mellitus Tipe 2 Di Poliklinik Penyakit Dalam Rumah Sakit Umum Pusat Fatmawati Jakarta. Universitas Indonesia.

Zimmet, P. (2009). Preventing Diabetic Complication: A Primary Care Prospective. Diabetes Research and Clinical Practice, 84, 107-116.. 